\title{
Focal eventration of diaphragm with fat content
}

\author{
Loganathan Nattusamy, ${ }^{1}$ Karan Madan, ${ }^{1}$ Jeyaseelan Nadarajah, ${ }^{2}$ Ashu Seith Bhalla ${ }^{2}$
}

${ }^{1}$ Department of Pulmonary Medicine and Sleep Disorders, All India Institute of Medical Sciences, New Delhi, India ${ }^{2}$ Department of

Radiodiagnosis, All India Institute of Medical Sciences, New Delhi, India

\section{Correspondence to} Dr Karan Madan, drkaranmadan@gmail.com

\section{DESCRIPTION}

A 60-year-old non-smoker female patient was referred for further evaluation for an incidentally detected chest radiographic abnormality. There were no previous cardinal chest symptoms. Chest radiograph (figure 1, left panel) and thoracic CT (axial sections; figure 1 , right panel) had demonstrated a rounded, homogenous, non-calcified opacity with smooth borders in the left lower zone, leading to consideration of a possibility of lung cancer. Image-guided fine needle aspiration cytology examination was planned subsequent to the chest radiograph findings. Careful review of the multiplanar thorax CT reconstruction images (figure 2) confirmed the diagnosis of focal eventration of the left diaphragm with fat content. The density was -80 Hounsfield units on CT corresponding to fatcontaining eventration. The patient was reassured and no further intervention was performed.

Eventration of diaphragm (congenital/acquired) is a condition wherein a part/whole of diaphragmatic muscle is replaced by fibroelastic tissue associated with intrathoracic herniation of abdominal contents. Diaphragmatic continuity and costal

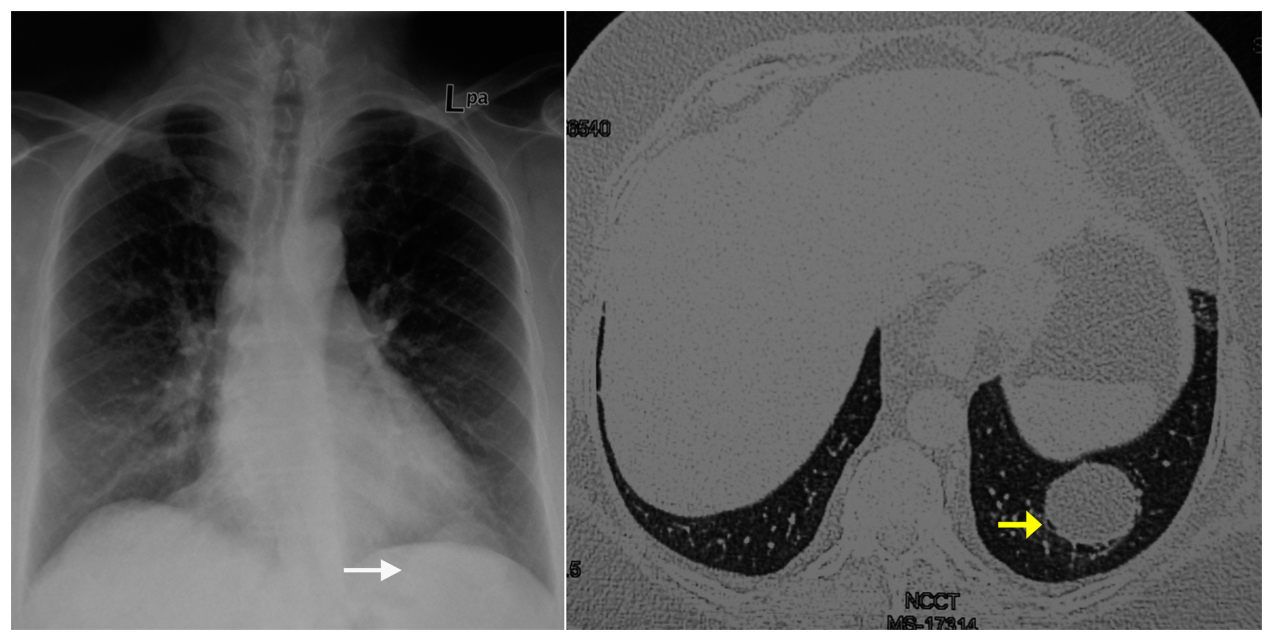

Figure 1 (left panel) Posteroanterior chest radiograph demonstrating a homogenous, non-calcified mass-like opacity in the left lower zone. (right panel) Axial sections of the thorax CT demonstrating a left lower lobe, non-spiculated opacity.
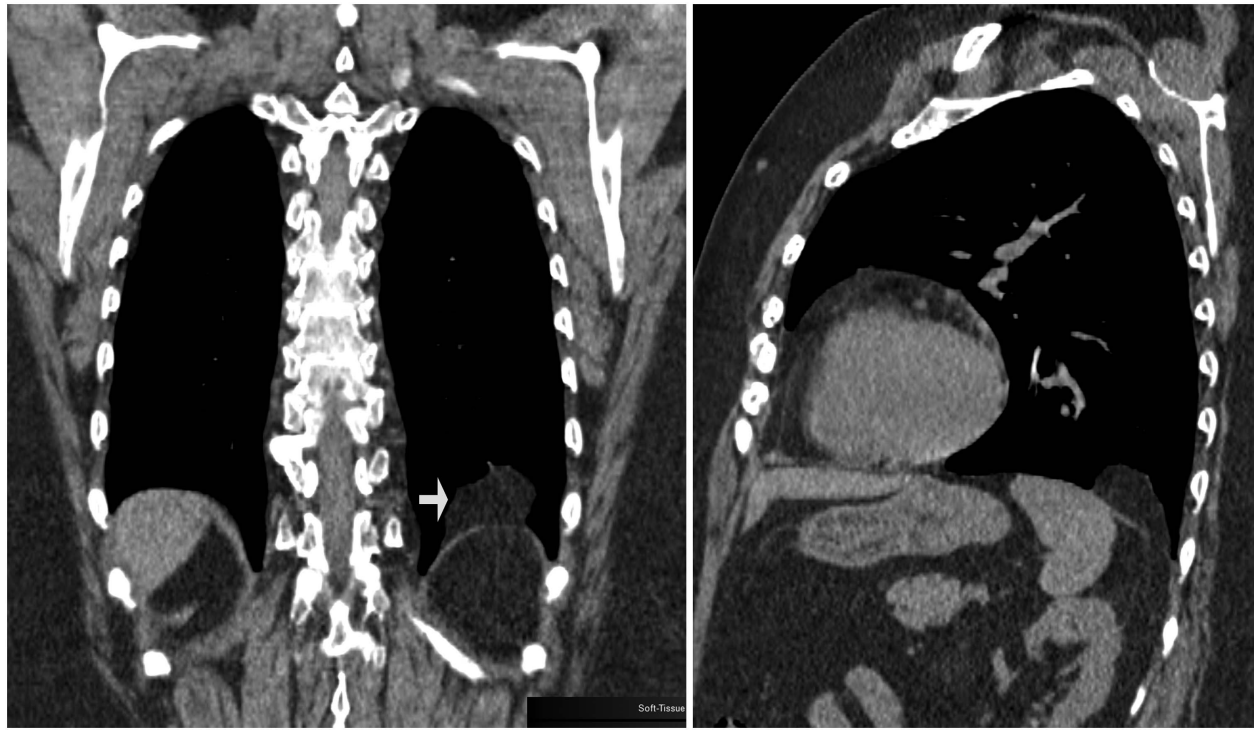

Figure 2 Coronal (left panel) and saggital (right panel) reconstruction images of the thoracic CT demonstrating focal eventration of diaphragm with intrathoracic herniation of fat content. 
attachment are, however, preserved. The condition is usually asymptomatic and detected as an incidental radiological finding. Phrenic nerve injury (traumatic/postsurgical) is the commonest cause of acquired eventration. ${ }^{1}$ If the CT slices are thicker, it can lead to a greater averaging of adjacent structures, which may be particularly problematic in imaging of lower thorax. ${ }^{2}$ The same

\section{Learning points}

- Eventration of diaphragm is usually diagnosed as an incidental, asymptomatic radiological finding on chest radiographs.

- Multiplanar reconstruction images of thoracic CT are particularly useful in evaluation of lesion in the lower thorax.

- Most patients with eventration of diaphragm do not require further management for the same. phenomenon (known as partial volume effect) can lead to the recognition of focal diaphragmatic abnormality like partial eventration in our case as an intrapulmonary abnormality on axial images. Multiplanar CT imaging can delineate anatomy with greater detail thereby enabling accurate diagnosis and therefore avoiding further unnecessary diagnostic procedures. Asymptomatic focal diaphragmatic eventration does not require any treatment.

Contributors LN and KM were involved in preparation of the manuscript, literature review and patient management. JN and ASB provided the radiology images.

Competing interests None.

Patient consent Obtained.

Provenance and peer review Not commissioned; externally peer reviewed.

\section{REFERENCES}

1 Deslauriers J. Eventration of the diaphragm. Chest Surg Clin N Am 1998;8:315.

2 Brink JA, Heiken JP, Semenkovich J, et al. Abnormalities of the diaphragm and adjacent structure: findings on multiplanar spiral CT scans. AJR Am J Roentgenol 1994;163:307-10.

Copyright 2014 BMJ Publishing Group. All rights reserved. For permission to reuse any of this content visit http://group.bmj.com/group/rights-licensing/permissions.

BMJ Case Report Fellows may re-use this article for personal use and teaching without any further permission.

Become a Fellow of BMJ Case Reports today and you can:

- Submit as many cases as you like

- Enjoy fast sympathetic peer review and rapid publication of accepted articles

- Access all the published articles

- Re-use any of the published material for personal use and teaching without further permission

For information on Institutional Fellowships contact consortiasales@bmjgroup.com

Visit casereports.bmj.com for more articles like this and to become a Fellow 